International Journal of Environment, Agriculture and Biotechnology
Vol-6, Issue-4; Jul-Aug, 2021
J Journal Home Page Available: https://ijeab.com/
Journal DOI: $10.22161 /$ ijeab

\title{
Orphaned and Abandoned Fruit Species from Panama, A Brief Thematic Review
}

\author{
Luis Wong Vega
}

Invited Professor, Office of the Vice-President for Research and Graduate Studies, Universidad de Panamá (UP), Panamá, Rep. of Panamá. Email: luis.wong.vega@gmail.com

Received: 10 Mar 2021; Received in revised form: 03 Apr 2021; Accepted: 10 Apr 2021; Available online: 18 Jul 2021

C2021 The Author(s). Published by Infogain Publication. This is an open access article under the CC BY license

(https://creativecommons.org/licenses/by/4.0/).

\begin{abstract}
The richness of Panama's biological heritage is highly significant. However, the scarce research work on its own national plant genetic resources focuses on a limited number of agricultural crops with high local consumption levels (grains, tubers, traditional tropical fruits) or on exportable items such as cucurbits (watermelon, melon), musaceae (banana, plantain) or bromeliads (pineapple), considered "priority species" by the Panamanian government. Non-traditional fruit species, considered "orphan" or in a clear state of abandonment, do not fall within the priorities already mentioned, which explains, to a large extent, their situation as native fruits practically not studied or not preserved and that have been steadily disappearing from the local consumption. We will review the status of these species and discuss possible actions for their recovery and enhancement.
\end{abstract}

Keywords - Tropical fruit growing, plant genetic resources, tropical fruit trees, orphan species, tropical agriculture, Panama.

\section{INTRODUCTION}

The Mexican researcher Francisco Zavala defines tropical fruit growing as: "The economic activity that takes place in all the tropical areas of the world, areas that are located between the tropics of Cancer and Capricorn, this part of the planet is located at $23^{\circ} 27$ North latitude and $23^{\circ} 27$ 'South latitude. The tropical zone is characterized by the uniformity of warm temperatures, a favorable factor for the productive development of several species of fruit trees... Tropical fruit growing is defined as an activity that grows edible fruits, which are consumed either fresh or processed. This (practice) is conducted in developing countries, considering that its geographical location is in the tropical zone, a factor that limits the development of research in these fruit trees, since most of the research has been carried out in fruit trees with a temperate climate, by developed countries that are located in temperate zones"(1).

This work focuses on the general state of Panamanian fruit growing and, above all, on the study of our native species, analyzing factors that determine their interest as food species and their potential for expanding their propagation and consumption, enriching the diet of the Panamanian people, helping to guarantee the conservation of these fruit species and to ensure our food security, based on our phytogenetic resources.

\section{STATUS OF THE PANAMANIAN FLORA}

The richness of the Panamanian national biological heritage is highly significant. The Fifth National Biodiversity Report clearly sums it up: "Panama is located in the region with the greatest biodiversity on the planet, among the six known centers of global biodiversity, with high altitude variations that, under tropical climate conditions, favor a diversity of ecosystems containing 12 of the 30 Holdridge Life Zones on the planet ... in addition to the 24 categories of vegetation proposed by UNESCO and the 7 additional categories that were included for the country that host an extensive variability of ecosystems and habitats that allow the establishment of many species "(2). 
In terms of vegetation, as this report mentions, "Panama has 21 times more plant species per $\mathrm{km}^{2}$ than Brazil... 3.5\% flowering plants and $7.3 \%$ ferns and the like in the world... there are between 1,300 and 1,900 species of plants... that they are endemic or unique to the country" (Ibidem).

The Fourth National Biodiversity Report of Panama (3) stated that "Panama has a published Catalog of Vascular Plants (2004), where 9,520 species of vascular plants distributed in 255 families were recorded; 8,560 Angiosperms, 22 Gymnosperms, and 938 Pteridophytes (ferns and allies). Of that total, 1,144 are endemic, until now they have only been registered in Panama".

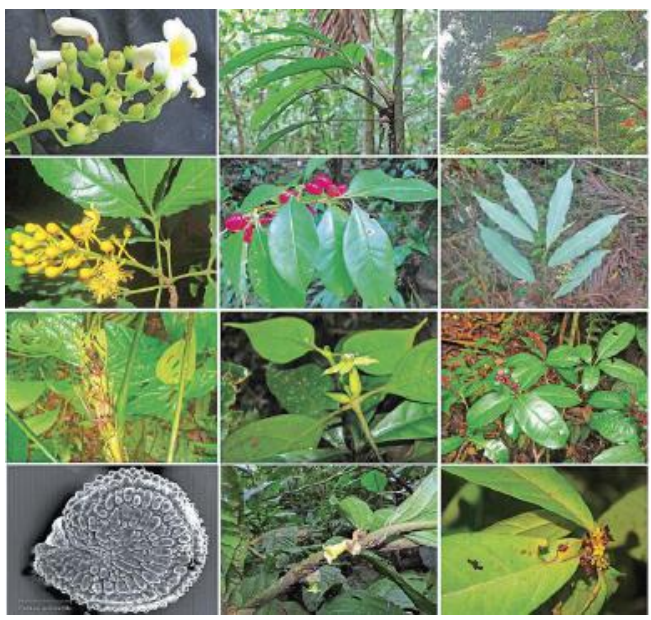

Fig. 1. Samples of the rich Panamanian flora (image from La Estrella De Panamá journal)

The Database of Indigenous Plants of Panama maintained by the Center for Tropical Forest Sciences (CTFS) of the Smithsonian Tropical Research Institute (STRI), contains descriptions of 1,213 trees, shrubs and palms and 278 species of lianas, all species present at throughout the country's geography (4).

According to the Fourth National Report on Panamanian Biodiversity, prepared in July 2010, there is a degree of scientific management and use of plant genetic resources in the country, when it states that: "Panama is a Contracting Party to the International Treaty on Plant Genetic Resources for Agriculture and Food. A National Commission of Plant Genetic Resources of Panama has been operating since 1999. Inventory studies and collections of wild species that are relatives of tropical crops are carried out (several institutions participating, including the Faculty of Natural, Exact and Technology Sciences of the University of Panama, Instituto de Investigaciones Agropecuarias de Panamá (IDIAP), STRI, among others). Working collections and germplasm banks exist in the Faculty of Agricultural Sciences of the University of Panama, and in the IDIAP. The use of Phytogenetic resources is wide, focused mainly on genetic improvement (Faculty of Agricultural Sciences of the University of Panama, Institute of Agricultural Research of Panama, and the Corporación Azucarera la Estrella, SA (CALESA). ANAM (2009) has contributed to the establishment of 29 nurseries of native forest species, 20 community nurseries and 115 private nurseries (Op.Cit)".

Curiously, the Fifth National Report on Biodiversity (Op.Cit.) shows that much of the above has not been translated into serious and significant progress in terms of preserving our biodiversity. The tenth meeting of the Conference of the Parties (COP10) held at the Nagoya summit, created the Aichi targets on Biodiversity 20112020. The Aichi Goals make up a set of 20 goals grouped around five Strategic Objectives, which the signatory countries should achieve by 2020. As the aforementioned Fifth Report recognizes, in Panama, in 2018, significant progress had only been made in 2 of the 20 goals and with some initial progress, only in 6 of the 20 strategic goals by the end of the second decade of this century. Something very worrying, due to its high level of non-compliance and its consequences on our biodiversity.

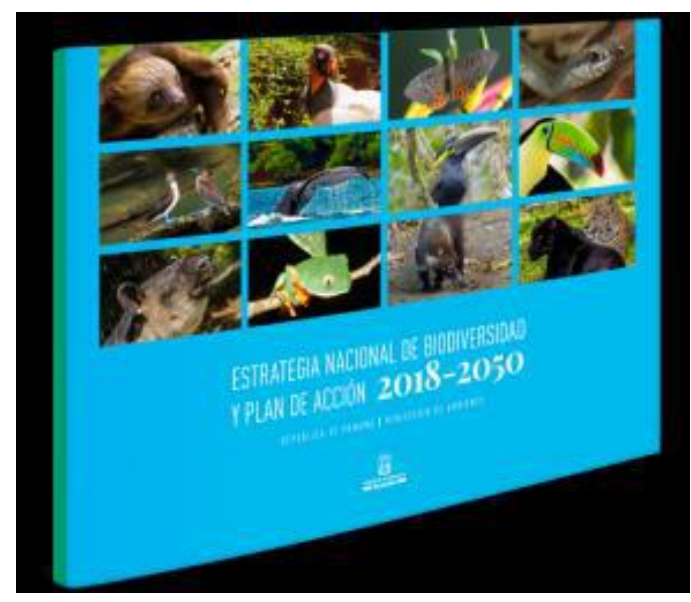

Fig. 2. Panama's National Biodiversity Strategy and Action Plan 2018-2050 (Image from UNDP-Panamá).

Even worse: of the 26 actions listed in the National Biodiversity Strategy and Action Plan 2018-2050, only one has direct relevance, as an implicit derivation, with the research and development of our plant genetic resources: Line 3.3. Promotion of Research on Biodiversity, Action 3.3.1. Promote specialized research on biodiversity and associated issues (5).

Today, it is an indisputable fact that the richness of the world's plant biodiversity (and above all, that of the tropics, including Panama) is in serious risk and in many cases, is suffering dangerous setbacks. The Food and Agriculture Organization of the United Nations (FAO), in its global report "The state of biodiversity for food and agriculture in 
the world", published in 2019, calls the alarm about the state of critical deterioration of biodiversity in the world.

On plant species, this document clearly states that "Of some 6,000 species of plants that are grown for food, less than 200 contribute substantially to world food production, and only nine represent $66 \%$ of the total production. agricultural ... $24 \%$ of nearly 4,000 wild food species - mostly plants, fish and mammals - are declining in number ... the proportion of wild foods in decline is likely to be even higher, as the status of more than half is unknown of the existing wild food species... The largest number of wild food species in decline is found in Latin American and Caribbean countries" (6).

The scarce research work on our national plant genetic resources focuses on a limited number of agricultural crops with high local consumption (grains, tubers, traditional tropical fruit trees) or on exportable items such as cucurbits (watermelon, melon), musaceae (banana, plantain) or bromeliads (pineapple). In other words, species defined by the determining entities of agricultural public policies as "priority species". A huge part of our plant genetic wealth, edible or not, is neglected.

\section{THE PRODUCTION AND CONSUMPTION OF FRUITS IN PANAMA, TODAY}

Fruit growing centered on traditional species is an important economic activity for certain sectors, although its net contribution to Gross Domestic Product (GDP) is relatively small, falling from $25 \% 40$ years ago to less than $3 \%$ today. According to the Ministry of Agricultural Development (MIDA): “9,775 producers are dedicated to planting and harvesting fruits on 39,788 hectares of land... The commercialization of Panamanian fruits such as pineapple, watermelon, lemon, papaya melon and avocado contribute more than US\$ 175 million annually to the GDP of Panama" (13).

Regarding Panamanian fruit production, MIDA states that: "Fruit production has increased in the last decade, especially that of cucurbits (melon and watermelon) and we must also mention the famous "chorrerana" pineapple, which are exported to American countries. and even Europeans... One of the points to be highlighted is that fruit production has been concentrated in Azuero and Panama Oeste regions, thus boosting the economies of these areas and boosting agricultural growth, with which many families subsist Panamanians, without forgetting to mention the other provinces that day by day do their job to produce the fruits that we consume.

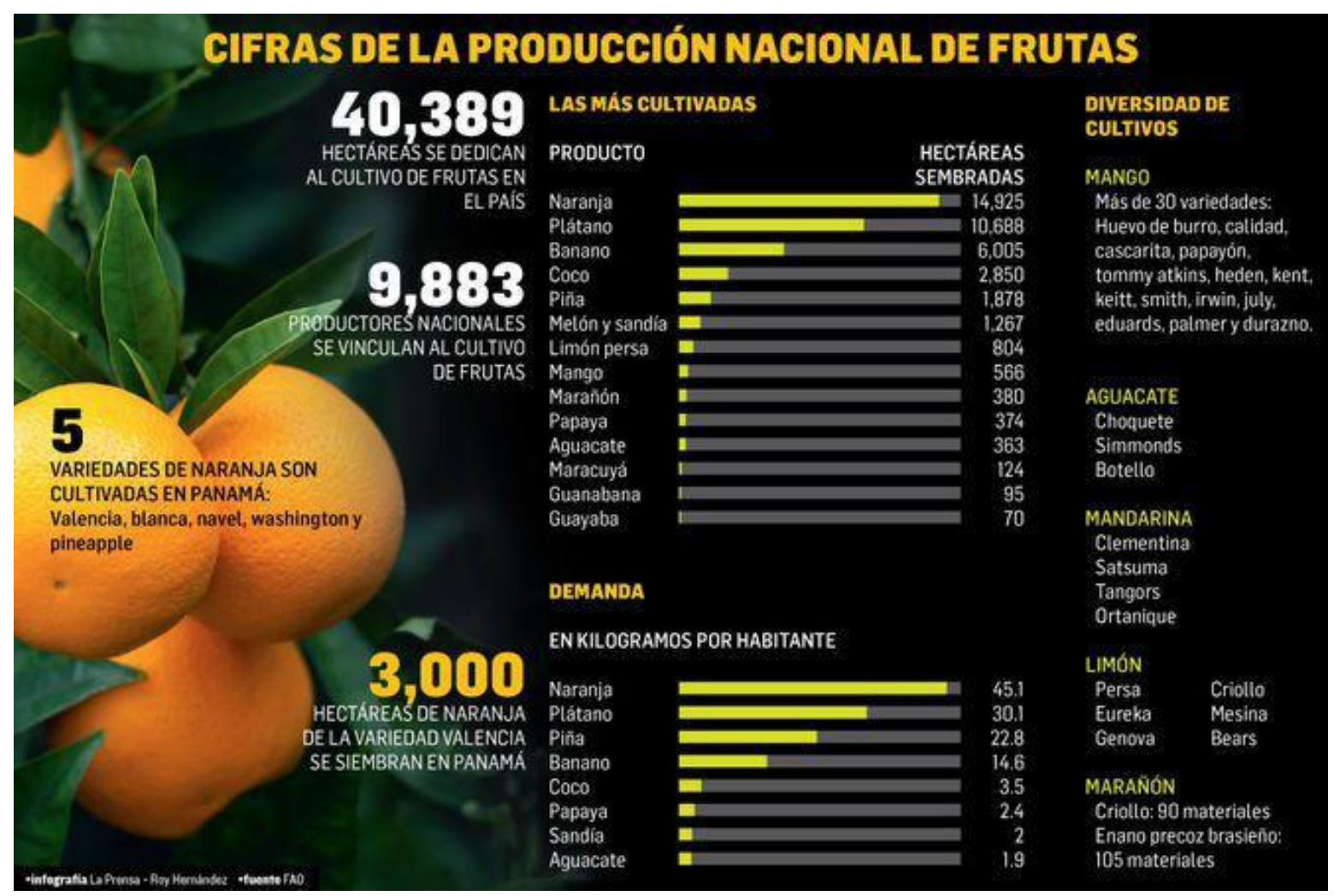

Fig. 3: Panama's National Fruit Production figures (Infographics by La Prensa journal, based on FAO 2019 data). 
Crop yield is increasing, indicating that growers achieve greater efficiency each season. However, national demand is increasing (as well), making this market more attractive ... In most Panamanian households, fruits are consumed fresh, as a dessert or as a snack for children and for people with special diets; They are also used in the preparation of drinks and smoothies to accompany meals. The highest consumption occurs in restaurants and hotels, where fresh fruits and juices are offered for breakfast, as light lunches, in salads and smoothies, or used in the preparation of desserts for lunches and dinners" (14).

But, on the contrary, the national press reflects many divergent opinions. For example, the nutritionist of the Caja de Seguro Social (Panama's social security agency), Mr. José Ramiro López, stated that "The consumption of this food in Panama is quite low compared to the recommendation of three times a day" (15). According to dietitian Ms. Karla Díaz: "In the Panamanian diet, the least consumed nutritional sources are vitamins and minerals, which are found in all the variety of fruits and vegetables available" (16). Likewise, according to the Panamanian Association of Nutritionists-Dietitians and the Ministry of Health, "studies show that the average consumption of fruits, legumes and vegetables is much lower than the minimum necessary for health protection" (17).

Panamanian fruit production focuses, as has already been stated, on some traditional tropical species for export to certain developed markets (United States, European Union, China) and to a lesser extent, on some tropical species for local consumption.
In the first group we could point to a series of species that are mass-produced and that are in high demand in the mentioned markets. For this reason, they are species that have been highly studied (even by large food multinationals such as Nestlé, Dole, Del Monte, Tropicana, Chiquita, etc.) from the agronomic point of view and that have been the subject of much research for their genetic improvement, seeking to modify its organoleptic aspects and its nutritional content.

Among this first list (or " $A$ " list) are species such as: Mango, Banana, Plantain, Pineapple, Melon, Watermelon, Passion Fruit, Avocado, Papaya, Citrus (Oranges, Grapefruits, Lemons, Limes, Tangerines), Cocoa, Coffee and Tea (18).

A second list (or "B" list) gathers species of great consumption within the Latin American region and that have a market share in developed countries, such as "exotic" fruit trees. Even these species (some tropical and others introduced and established for a long time) have different degrees of agro-industrial transformation, which is why they have been the subject of agrotechnical studies at an important level. In this list we have species such as: Soursop or Guanábana, Pineapple Guava or Feijoa, Dragon Fruit or Pitahaya, Goldenberry or Uchuva, Tamarillo or Tree Tomato, Guava or Guayaba, Tamarind, Peach Palm or Pixbae, Cashew or Marañón, Star Fruit or Carambola, Coconut, Rambutan, Mangosteen, Macadamia and even Nopal (Íbidem), among others.

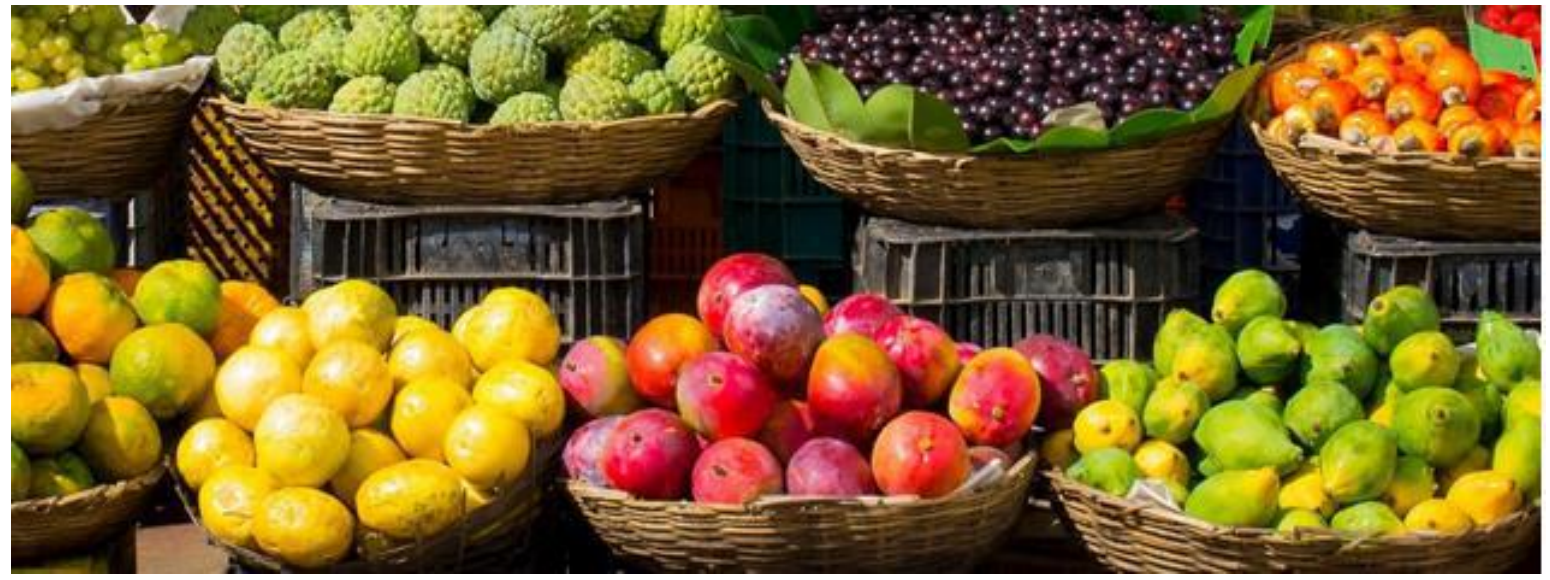

Fig. 4. Panamanian Exotic Fruits (Image from La Prensa journal).

\section{THE FRUIT WEALTH OF THE COUNTRY}

There is little specific information on Panamanian nontraditional fruits, listing and / or describing the relevant species.
About 70 years ago, Dr. Robert Harris, a scientist at the Massachusetts Institute of Technology (MIT), mentioned just over 230 native species of edible plants with high nutritional content, in Central America and Panama (7), many of which are species fruit trees. 
In 2009, the National Institute of Biodiversity (InBio) of Costa Rica published a book called "Edible Plants of Central America", which includes Panama. In its introductory section, this text indicates that: "The floristic richness and the cultural development of Central America have made important contributions to the food security of humanity. Corn, cocoa, beans, and chili peppers are just a few examples. In addition to these plants widely cultivated throughout the world, the region has a large number of edible species, many of which lack extensive cultivation technologies or are still collected directly from their natural environment, through artisanal practices" (8).

This book has technical data sheets on 103 edible species, the vast majority of which are fruits and of which just over $80 \%$ are present in Panama. On the other hand, this study leaves out several important orphan Panamanian fruit species.

The author Oris J. Donoso, in her work "Some plants used by the native groups of Panama" reviews 22 non-traditional and 4 traditional fruit species (9), based mainly on the text of Chizmar et al. (Op. Cit.).

In 2011, Carolina Reyes Acosta, a student from the Pontificia Universidad Javeriana de Bogotá, Colombia, with the support of the Center for Environmental and Human Development (CENDAH-Facilitadores) conducted a field study within communities of the San Blas islands, which generated, as a final product, the book "Plants of traditional use in the indigenous region of Guna Yala". The text lists and describes plant species for private consumption in the original Guna population (10), some of which are nontraditional tropical fruit species.

As already mentioned, for a few years, the CTFS-STRI has maintained an important "digital repository of trees, shrubs and common palms of Panama" called "Tree Atlas of Panama", with information on almost 1,500 Panamanian plant species, including a good part of the fruit species, known or unknown, in the country (11).

In 2017, the book "Catalog of native plants with potential for biotrade and bioprospecting of the private natural reserve Punta Patiño, Darién, Panama" was published, which examines 22 plant species, many of them oleaginous fruit spices (12).

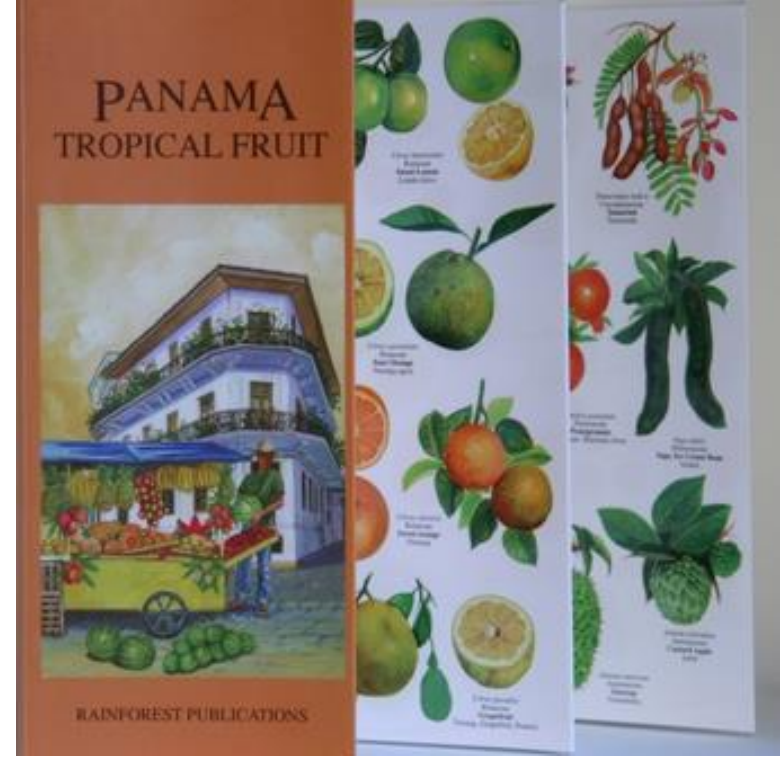

Fig. 5: "Panama Tropical Fruits", published in the Netherlands by Rainforest Publications (ISBN 1888538796-1).

\section{OUR ORPHAN SPECIES}

As the International Plant Genetic Resources Institute (IPGRI) points out: "Abandoned, forgotten, orphaned, neglected or traditional crops are those that are grown only in their centers of origin in a traditional way and that are important for the subsistence of families. rural ... Underutilized crops are products that were of commercial importance and today their popular presence in local markets has diminished and they are no longer appreciated" (19). They are increasingly unknown by consumers.

As already mentioned, both the agricultural and environmental Panamanian authorities have defined priorities regarding the preservation of plant genetic biodiversity, including those that have agri-food use or potential. For example, in 2009, the Panama's Ministry of Agricultural Development launched the initiative called "Promotion and Competitiveness of the Fruit Subsector", which established that: "The direct beneficiaries of the actions to be carried out by the project will be approximately 1,150 producers for an incremental surface of 3,500 hectares of new plantations in the first 5 years of execution (an average of 3 hectares per producer) prioritizing eight fruits: avocado, passion fruit, papaya, banana, mango, cashew, guava and orange juice "(20). This criterion and those "priorities" continue to this day.

Obviously, the fruit species considered "orphan" or in a state of abandonment, do not fall within the priorities already mentioned, which explains, to a large extent, their situation as native fruits that have been disappearing from local consumption. 
However, there is awareness in a part of the population regarding the gradual loss of many of these species. In the report "The Fruits that were lost", the local newspaper La Prensa describes that, previously, "they did not have to go very far to find algarrobas, higo, jobo, cañafístula, grosella, guinda, piro, toreta, uvita de parra, cuate, guabita cansaboca, piñuela, níspero, corozo, pomarrosa and caimito, fruits that were abundant in almost all the fields of the interior countryside ... But today these fruits have practically disappeared, so they are unknown to new generations ... Curiously, the country has a high consumption of fruits from a temperate climate, such as apple, grape and pear" (21).

In an interesting journalistic work from a few years ago, $\mathrm{Mr}$. Ángel Carril, fruit growing coordinator of the National Directorate of Agriculture of the Ministry of Agricultural Development (MIDA) in Santiago, Veraguas, pointed out that: "many tropical fruits native to Panama do not They are found with the same frequency as several decades ago ... Some of them are: la fruta de pan, el caimito, zapote, mamey, chirimoya, mangotín, guaba, guabita cansaboca, corozo, nance, níspero, jobo, pomarrosa, ciruela, guayaba criolla, toreto and borojó... This is a list of fruits that we have identified. As lately we have been working at the field level, we have observed that many of the producers have emphasized to us that these fruits have been disappearing ... These fruits are no longer seen as frequently due to factors such as: rapid population growth, environmental effects such as drought and floods, invasive species, overgrazing, burning, deforestation, among others... Before, people used to sow in the backyard. Now it cannot, as today's typical urbanization model does not allow people to plant; suddenly yes a rose and some palm trees, but the physical residential space that was traditionally wide before has now been reduced, and that means that people do not plant, and if they plant, they do it in small quantities ... so that these fruits are not lost, at least rescue their genetic material, because that is where the future of fruit growing practically lies, and create community nurseries to try to maintain them "(22).

Our "C" list is the list of our native orphan fruits and includes, for the most part, abandoned native species, but also some introduced species that have been largely lost. It includes species of primary consumption by our native peoples, for example: white cacao and pataste (NgäbeBuglé and Bokotá nations), jagua and guásima (EmberáWounaan nation), membrillo and piro (Guna nation). Also, many native fruits that were cultivated and consumed in the Panamanian countryside but that today are practically not found in markets and hardly in our fields.

Some of these species were introduced during the Spanish colony era or during major events of foreign presence (arrival of foreigners for the construction of the intercontinental railroad, the French canal or the interoceanic canal by the North Americans, with the consequent immigration of various human groups of various ethnicities). Species such as pomegranate, sarsaparilla, Curaçao cashew or rose apple, were introduced this way. Also, species that were brought by the AfroAntilleans, such as akee, sorrel and breadfruit. All were consumed significantly during the late nineteenth century and a good part of the twentieth century.

All these introduced species and those of many of our native fruit trees, for various reasons (such as the strong influence of American culture, the relatively fast urbanization, the cosmopolitanism in terminal cities, the commercial opening towards food staples imports), began to stop being propagated and, therefore, to gradually disappear from the local fruit supply to the point that, at present, they are practically inaccessible and the last generations of Panamanians are even unaware of the existence of these species.

Table.1: Panamanian Orphan Fruit species

\begin{tabular}{|c|c|c|c|}
\hline $\begin{array}{l}\text { Spanish (Panamanian) } \\
\text { common name }\end{array}$ & English common name & Scientific name & Bothanical Family \\
\hline Akí or Fruto de Huevo & Akee & Blighia sapida & Sapindaceae \\
\hline Algarrobo & Carob & Hymenaea courbaril & Fabaceae \\
\hline Almendra tropical & Indian almond & Terminalia catappa & Combretaceae \\
\hline Anón & Sugar apple & Annona squamosa & Annonaceae \\
\hline Borojó & Borojo & Borojoa patinoi & Rubiaceae \\
\hline Cacao blanco & Capuassu & Theobroma grandiflorum & Malvaceae \\
\hline Caimito & Star apple & Chrysoplillum caimito & Sapotaceae \\
\hline Canistel or Nisperillo & Canistel & Pouteria campechiana & Sapotaceae \\
\hline
\end{tabular}




\begin{tabular}{|c|c|c|c|}
\hline Cañafístula & $\begin{array}{l}\text { Golden shower, purging } \\
\text { cassia, Indian laburnum, } \\
\text { or pudding-pipe tree }\end{array}$ & Cassia fistula & Fabaceae \\
\hline Cereza or Acerola & Barbados Cherry & Malpighia emarginata & Malpighiaceae \\
\hline Chirimoya & Cherimoya & Annona cherimola & Annonacea \\
\hline $\begin{array}{l}\text { Ciruela Traqueadora or } \\
\text { Mercoya }\end{array}$ & $\begin{array}{l}\text { Red Mombin, Purple } \\
\text { Mombin }\end{array}$ & Spondias purpurea & Anacardiaceae \\
\hline $\begin{array}{l}\text { Corozo or Palma de } \\
\text { Pacora }\end{array}$ & N/A & Acrocomia panamensis & Arecaceae \\
\hline Fruta de Pan & Bread Fruit & Artocarpus altilis & Moraceae \\
\hline Granada & Pomegranate & Punica granatum & Lythraceae \\
\hline Granadilla & Sweet Granadilla & Passiflora ligularis & Passifloraceae \\
\hline Grosella & $\begin{array}{l}\text { Otaheite Gooseberry, } \\
\text { Malay Gooseberry }\end{array}$ & Phyllanthus acidus & Phyllanthaceae \\
\hline Guaba & Ice Cream Bean & Inga edulis & Fabaceae \\
\hline Guabita Cansaboca & N/A & Inga laurina & Fabaceae \\
\hline Guásima & $\begin{array}{l}\text { West Indian Elm or Bay } \\
\text { Cedar }\end{array}$ & Guazuma ulmifolia & Malvaceae \\
\hline Guayabita sabanera & $\begin{array}{l}\text { Brazilian } \quad \text { Guava, } \\
\text { Castilian Guava, Sour } \\
\text { Guava }\end{array}$ & Psidium guineense & Myrtaceae \\
\hline Guinda & $\begin{array}{l}\text { Black Cherry, Wild } \\
\text { Black Cherry }\end{array}$ & Prunus salicifolia & Rosaceae \\
\hline Guineo manzano & Dwarf banana & Musa sapientum & Musaceae \\
\hline Icaco & Cocoplum & Chrysobalanus icaco & Chrysobalanaceae \\
\hline Jagua & Genipap & Genipa americana & Rubiaceae \\
\hline Jobo & $\begin{array}{l}\text { Yellow Mombin, Hog } \\
\text { Plum }\end{array}$ & Spondias mombin & Anacardiaceae \\
\hline Madroño & N/A & Rheedia madrunno & Clusiaceae \\
\hline Majaguillo or Capulín & Puan & Muntingia calabura & Muntingiaceae \\
\hline Mamey & $\begin{array}{l}\text { Mammee, } \quad \text { Mammee } \\
\text { Apple }\end{array}$ & Mammea americana & Calophyllaceae \\
\hline Mamón, Mamoncillo & Genip, Kenep & Melicoccus bijugatus & Sapindaceae \\
\hline Mangotín & June Plum & Spondias cytherea & Anacardiaceae \\
\hline Maquenca & N/A & Coccoloba lasseri & Polygonaceae \\
\hline $\begin{array}{l}\text { Marañón Curazao, } \\
\text { Manzana de Agua }\end{array}$ & $\begin{array}{l}\text { Malay Apple, Otaheite } \\
\text { Apple }\end{array}$ & Syzygium malaccense & Myrtaceae \\
\hline Membrillo & $\begin{array}{l}\text { Sachamango, Heaven } \\
\text { Lotus }\end{array}$ & Gustavia superba & Lecythidaceae \\
\hline Nance & $\begin{array}{l}\text { Savanna Serret, Golden } \\
\text { Spoon, Hogberry }\end{array}$ & Byrsonima crassifolia & Malpighiaceae \\
\hline Naranjilla, Lulo & Naranjilla & Solanum quitoense & Solanaceae \\
\hline
\end{tabular}




\begin{tabular}{|l|l|l|l|}
\hline Nonita & $\begin{array}{l}\text { Custard Apple, Wild } \\
\text { Sweetsop }\end{array}$ & Annona reticulata & Annonaceae \\
\hline Pataste, Mocambo & Mocambo tree & Theobroma bicolor & Malvaceae \\
\hline Piñela & N/A & Bromelia pinguin & Bromeliaceae \\
\hline Piro & N/A & Bromelia karatas & Bromeliaceae \\
\hline Pomarrosa & Rose Apple & Syzygium jambos & Myrtaceae \\
\hline Sapote, Mamey de tierra & Sapodilla, Nooseberry & Pouteria zapota & Sapotaceae \\
\hline Saril, Flor de Jamaica & Sorrel, Roselle & Hibiscus sabdariffa & Malvaceae \\
\hline Toreta & Soncoya, Sincuya & Annona purpurea & Annonaceae \\
\hline Uva de playa & Sea Grape, Bay Grape & Coccoloba uvifera & Polygonaceae \\
\hline Uvita & N/A & Bactris maraja & Arecaceae \\
\hline Zapote & Sapodilla & Manilkara zapota & Sapotaceae \\
\hline Zapote Teta de Chola & Chupa & Quararibea cordata & Malvaceae \\
\hline Zarzamora & Blackberry & $\begin{array}{l}\text { Rubus fruticosus or Rubus } \\
\text { ulmifolius }\end{array}$ & Rosaceae \\
\hline
\end{tabular}

(Infographics by the author).

\section{FINAL CONSIDERATIONS}

Regarding ideas to reverse this situation, there should be a reorientation of agricultural public policies in many areas, including the issue of native species, which should receive much more attention from the sectoral governing bodies. This should lead to a redefinition and expansion of what is understood as a priority species. Consequently, towards the agrotechnological study, preservation, propagation and sustainable use of more native plants, including orphan fruit species. This also implies their inclusion in the group of plant species with potential for agricultural exportation and their rational exploitation and promotion towards internal and external markets.

From an environmental and conservation perspective, firm actions must be taken for their management and conservation. It is not enough to preserve samples in herbaria. Inventories should be made targeting these particular species, as well as the establishment of one or more national genebanks for orphan species, as preliminary steps for their massive propagation and reintroduction in the field (community nurseries and gardens, individual farmers) and into their ecological niches.

The biotechnological study (especially through plant tissue culture techniques) of these species would be much valuable, from a botanical and agronomic perspective. Much of this would add new and useful scientific knowledge and would represent a significant contribution to the care of our plant genetic heritage and to the diversification of our national fruit production, based on state-of-the-art agrotechnologies.

From a cultural and health perspective, they should be studied, revalued and included in programs that rescue foods form former times, for the current Panamanian daily diet and to integrate them as valuable elements of the Panamanian gastronomic-cultural heritage, typical of the country.

\section{REFERENCES}

[1] https://sites.google.com/site/carecgeneticos/my-reading-list

[2] https://www.cbd.int/doc/world/pa/pa-nr-05-es.pdf

[3] https://www.cbd.int/doc/world/pa/pa-nr-04-es.pdf

[4] http://ctfs.si.edu/webatlas/mainframe.php?order=s

[5] Ministerio de Ambiente. 2018. Estrategia y Plan de Acción Nacional de Biodiversidad 2018-2050 de Panamá. Panamá, Ciudad de Panamá. 136 pp.

[6] https://elcapitalfinanciero.com/la-biodiversidad-crucialpara-la-alimentacion-y-agricultura-desaparece-cada-diasenala-informe-de-la-fao/

[7] http://www.iris.paho.org/xmlui/bitstream/handle/12345678 9/11774/v29n8p841.pdf

[8] Chízmar Fernández, Carla et al. (2009). Plantas comestibles de Centroamérica. Primera edición. Instituto Nacional de Biodiversidad (InBio), Santo Domingo de Heredia, Costa Rica.

[9] https://es.slideshare.net/orisdonoso/algunas-plantasconsumidas-por-los-grupos-originarios-de-37657678

[10] http://gubiler.blogspot.com/2011/06/plantas-de-uso$\underline{\text { tradicional-en-la.html }}$

[11] http://ctfs.si.edu/webatlas/maintreeatlas.php 
[12] ANCON, 2017. Catálogo de plantas nativas con potencial para biocomercio y bioprospección de la Reserva Natural Privada Punta Patiño, Darién - Panamá. Ministerio de Ambiente, GIZ, PNUD, GEF, IDIAP, Panamá. 56 pág.

[13] https://elcapitalfinanciero.com/comercializacion-de-frutasaporta-mas-de-175-millones-a-la-economia-de-panama/

[14] https://www.mida.gob.pa/noticias id 4757.html

[15] https://www.metrolibre.com/cultura/67541-panamenosconsumen-poca-fruta-nutricionistas.html

[16] https://impresa.prensa.com/vivir/dietapobre_0_3298170270.html

[17] https://frutasdepanama.blogspot.com/2013/05/frutas-depanama.html

[18] Wong Vega, Luis (2007). Biotechnology of Non-traditional Fruit species in Mesoamerica. Abstracts of the Second International Congress of Tropical Fruticulture. Guayaquil, Ecuador.

[19] International Plant Genetic Resources Institute (IPGRI). 2002. Neglected and Underutilized Plant Species: Strategic Action Plan of the International Plant Genetic Resources Institute. International Plant Genetic Resources Institute, Rome, Italy. 27 pp.

[20] http://repiica.iica.int/DOCS/B3138E/B3138E.PDF

[21] https://www.prensa.com/impresa/panorama/frutasperdieron 0 3245675641.html

[22] https://www.prensa.com/impresa/vivir/Frutasantano_0_3950605049.html

[23] Dirección de Inteligencia Comercial, ProEcuador. Análisis sectorial de frutales no-tradicionales. Quito, Ecuador, 2012, $24 \mathrm{pp}$.

[24] FAO. "Neglected crops need a rethink - can help world face the food security challenges of the future, says Graziano da Silva". FAO Media Centre. December 2012.

[25] Hammer, k.; Heller, J.; Engels, J. "Monographs on underutilized and neglected crops". Genetic Resources and Crop Evolution. 48 (1): 3-5. February 2001.

[26] IDIAP. Segundo Informe Nacional: Estado de los Recursos Fitogenéticos para la Alimentación y la Agricultura en Panamá. Panamá, 2010. 80 p.

[27] IICA. La Fruticultura en Panamá: su potencial socioeconómico e iniciativas para su desarrollo (IICA / MIDA /IDIAP). Panamá: IICA, 2008.167 p.

[28] IPGRI. Neglected and underutilized plant species: Strategic Action Plan of the International Plant Genetic Resources Institute. International Plant Genetic Resources Institute. ISBN 92-9043-529-1. 2002.

[29] IPGRI. Strategic Framework for Underutilized Plant Species Research and Development: With Special Reference to Asia and the Pacific, and to Sub-Saharan Africa. Bioversity International, 2006. 33 p.

[30] Álvarez Salas, L.M.; Gálvez, A.; Abadía, E.; Salazar Zapata, J.C.. Etnobotánica del Darién, Caribe colombiano: los frutos del bosque. Etnográfica, vol. 20 (1) 2016, 193-193

[31] Organización de las Naciones Unidas para la Agricultura y la Alimentación (FAO). Manual de manejo postcosecha de frutas tropicales.

http://www.fao.org/inpho/content/documents/vlibrary/ac30 $\underline{4 \mathrm{~s} / \mathrm{ac} 304 \mathrm{~s} 00 . \mathrm{htm}}$
[32] Patiño Rodríguez; V.M. Historia y dispersión de frutales nativos del neotrópico. Cali, Colombia: Centro Internacional de Agricultura Tropical, 2002, 665 p.

[33] Ramírez-Galindo, J., Cruz-Castillo, J.G., Gallegos-Vázquez, C., Espíndola-Barquera, M. de la C., Nieto-Ángel, R., Avendaño-Arrazate, C.H., Domínguez-Álvarez, J. L., Villegas-Monter, A., Ávila-Reséndiz, C., Arreola-Ávila, J., Armella-Villalpando, M. A., Hernández-Fuentes, L. M., Padilla-Ramírez, J. S., Betancourt-Olvera, M., Moreno Martínez, J.L., y Méndez-Valverde, A. R. 2016. Conservación y aprovechamiento Sostenible de Frutales Nativos de México. Servicio Nacional de Inspección y Certificación de Semillas y Universidad Autónoma Chapingo. México. 79 pp.

[34] Williams; J.T. y Haq, N. Global research on underutilized crops - an assessment of current activities and proposals for enhanced cooperation. Southampton, UK: International Centre for Underutilized Crops. ISBN 92-9043-545-3. 2002. 